\title{
Assessment of the Potential Contribution of the Ceramic Filter "Songhai" in the Treatment of Drinking Water in Benin (West Africa)
}

\author{
Roch Christian Johnson'1, Gratien Boni' ${ }^{1}$ Cyriaque Degbey², Karel Togbe ${ }^{1}$, \\ Hermione Amoukpo', Michel Boko ${ }^{1}$ \\ ${ }^{1}$ Laboratory of Hygiene, Sanitation, Toxicology and Environmental Health, Interfaculty Center of Training and \\ Research in Environment for the Sustainable Development, University of Abomey-Calavi (CIFRED-UAC), \\ Cotonou, Benin \\ ${ }^{2}$ Regional Institute of Public Health, University of Abomey-Calavi, Cotonou, Benin \\ Email: rochchristianjohnson@gmail.com
}

Received 9 June 2015; accepted 5 July 2015; published 8 July 2015

Copyright (C) 2015 by authors and Scientific Research Publishing Inc.

This work is licensed under the Creative Commons Attribution International License (CC BY). http://creativecommons.org/licenses/by/4.0/

(c) (i) Open Access

\section{Abstract}

Contamination of domestic water sources by the biological and physico-chemical pollutants remains a public health issue in Benin. The household water purification devices such as ceramic filters may be a solution. "Filtre Songhaï" is a ceramic filter, accessible and easy to use, marketed in Benin. The purpose of this study is to assess the contribution of the "Filtre Songhaï" in the treatment of water for domestic use in a peri-urban area in Porto-Novo (Benin). Water samples have been taken, from a collective well and from the lagoon in the 5th district of Porto-Novo. The physico-chemical and bacteriological parameters were measured before and after filtration. The results showed that the use of filters has allowed for a reduction of $97.5 \%$ for total coliform in the well water and $\mathbf{9 9 . 0 5 \%}$ for water from the lagoon. The reduction is $\mathbf{1 0 0 \%}$ for Escherichia coli and fecal streptococci in both cases. Given the low cost and the lifetime use of "filtre Songhai", this device can be recommended to households for drinking water, particularly for children below five years old the most vulnerable to water related diseases. Research is still necessary to improve the filtration time of this device.

\section{Keywords}

Drinking Water, “Filtre Songhai”, Porto-Novo, Bénin 


\section{Introduction}

According to the WHO/UNICEF 2013 report on progress in sanitation and water supply, 768 million people live without access to an improved water source and 185 million people use the surface water for their daily needs mainly in Africa [1]. The water quality is largely influenced by human activities and water found in nature is often polluted. The improved water supply shortage affects health with negative consequences on productivity and personal hygiene [2]. In Benin, despite efforts in water supply, assessment to improved water is still difficult especially in rural and suburban areas and households resort to unimproved water such as surface water and well water. Several studies conducted in Benin showed that the wells are often contaminated in proportions exceeding the WHO standard by various pathogens such as Escherichia coli, Klebsiella pneumoniae, Staphylococcus aureus, Salmonella spp, Clostridium perfringens, etc. [3] [4]. According to the Ministry of Health of Benin, each year, 4300 children under five years old die of diarrhea [5]. Interventions aiming at the purification of water at point of use may then be offered to households to improve the quality of drinking water. Among these, ceramic filters marketed in Benin under the name "Filtre Songhaï" can be offered to households.

These filters are made locally with a mixture of clay, sawdust and water; modeled in custom molds (Figure 1 and Figure 2). Once dried, baked in an oven of $900^{\circ} \mathrm{C}$ and cooled, the filters having a good filtration rate are immersed in a solution of water and colloidal silver [5]. This treatment improves the filter efficiency [5]. The benefits of these filters are their ease of use, long service life and their relatively low cost.

The objective of this study is to assess the potential contribution of the "Filtre Songhaï" in improving the quality of water for domestic uses in the 5th district of Porto Novo, a suburban district of the political capital of Benin.

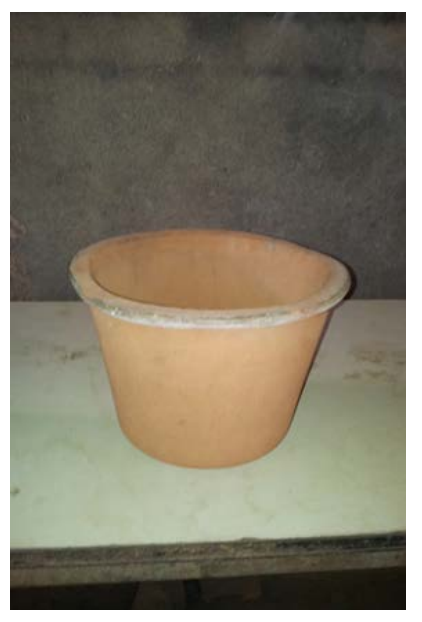

Figure 1. Filter.

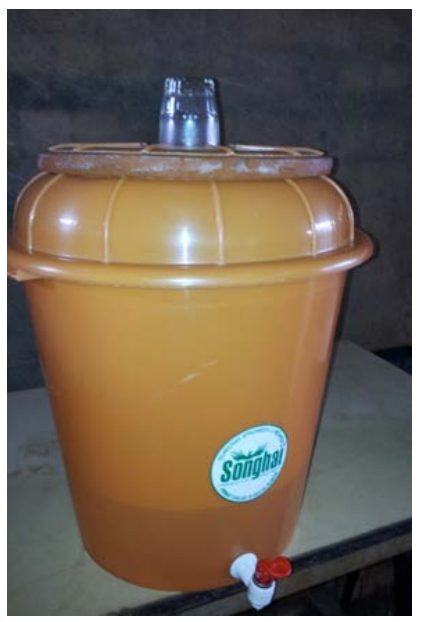

Figure 2. Device of the filter. 


\subsection{Study Sites}

Located at $30 \mathrm{~km}$ from Cotonou, the city of Porto-Novo is located between $6^{\circ} 30^{\prime}$ Latitude North and $3^{\circ} 30^{\prime}$ East Longitude. It covers an area of $52 \mathrm{~km}^{2}$ with a population of 263,616 inhabitants [6]. Porto-Novo has five (5) districts. The 5 th district covers an area of approximately $14.25 \mathrm{~km}^{2}$ and a population estimated at 82,430 inhabitants. The sampling of the water of the lagoon was conducted at the landing to Djassin-Topka, a neighborhood of PortoNovo. As for the well water, the sample was collected from a collective well located Djassin Zoumean outlying district of the 5th arrondissement.

\subsection{Sampling}

The water samples were collected in glass vials of $500 \mathrm{ml}$. These vials were previously washed, rinsed and dried in the laboratory. They were then sealed and wrapped in aluminum foil and sterilized at $121^{\circ} \mathrm{C}$ for 30 minutes.

Transportation from the sampling point to the laboratory was made in a cooler at $4^{\circ} \mathrm{C}$. The physico-chemical and microbiological parameters were measured in samples taken at each source, before and after the experiment.

Two filters were selected and numbered 1 to filter well water and filter 2 for water of the lagoon.

\subsection{Bacteriological and Physicochemical Analyzes}

The $\mathrm{pH}$ and conductivity were measured in situ using a multi-parameter. The color measurement was obtained using a spectrophotometer. The turbidity meter was used to measure the turbidity. Nitrates have been detected by the cadmium reduction method on a molecular absorption spectrophotometer DR 2800. Nitrites have been identified by the diazotization method. Phosphates were measured through the molecular absorption spectrophotometer DR 2800. The microbiological analyzes were carried out within twelve hours of the sample collection. Fecal coliforms, total coliforms and fecal streptococci were detected by routine methods (NF V08-051 February 1999).

\section{Results}

\subsection{Physico-Chemical Parameters of Well Water and Water of the Lagoon}

Table 1 and Table 2 show the results of physico-chemical parameters before and after filtration of well water samples (Table 1) and Lagoon (Table 2).

\subsection{Microbiological Parameters of Well Water and Water of the Lagoon}

Table 3 and Table 4 show the results of bacteriological parameters before and after filtration of well water samples (Table 3) and lagoon (Table 4). There is a significant reduction of microbiological contaminants both for well water and water from the lagoon.

Table 1. Results of the physicochemical parameters of well water before and after filtration.

\begin{tabular}{|c|c|c|c|}
\hline Parameters & Before filtration & After filtration & WHO standards \\
\hline $\mathbf{p H}$ & 4.38 & 7.54 & $6.5 \leq \mathrm{pH} \leq 8.5$ \\
\hline Temperature $\left({ }^{\circ} \mathrm{C}\right)$ & 25.3 & 25.9 & - \\
\hline Conductivity $(\mu / \mathrm{cm})$ & 122.6 & 265 & $\leq 1000$ \\
\hline Color (UCV) & 22 & 20 & 15 \\
\hline Turbidity (NTU) & 4.4 & 4 & $\leq 5$ \\
\hline Nitrate (mg/l) & 33.44 & 33.44 & $\leq 50$ \\
\hline Nitrite (mg/l) & 0.0627 & 0.0363 & $\leq 3$ \\
\hline Ammonium (mg/l) & 2.01 & 0.03 & - \\
\hline Phosphate (mg/l) & 1.99 & 44.13 & - \\
\hline
\end{tabular}

Source: result of the analyses DGEAU, 2014. 
Table 2. Results of the physicochemical parameters of water from the lagoon before and after filtration.

\begin{tabular}{cccc}
\hline Parameters & Before filtration & After filtration & WHO standards \\
\hline $\mathbf{p H}$ & 6.58 & 6.97 & $6.5 \leq \mathrm{pH} \leq 8.5$ \\
Temperature $\left({ }^{\circ} \mathbf{C}\right)$ & 25.2 & 25.3 & - \\
Conductivity $(\boldsymbol{\mu} / \mathbf{c m})$ & 8390 & 6670 & $\leq 1000$ \\
Color $(\mathbf{U C V})$ & 40 & 13 & 15 \\
Turbidity(NTU) & 8 & 2.6 & $\leq 5$ \\
Nitrate $(\mathbf{m g} / \mathbf{l})$ & 1.76 & 11 & $\leq 50$ \\
Nitrite $(\mathbf{m g} / \mathbf{l})$ & 0 & 0.1 & - \\
Ammonium $(\mathbf{m g} / \mathbf{l})$ & 0.86 & 0.02 & - \\
Phosphate $(\mathbf{m g} / \mathbf{l})$ & 2.93 & 24.91 & $\leq 3$ \\
\hline
\end{tabular}

Source: result of the analyses DGEAU, 2014.

Table 3. Results of the bacteriological parameters of well water before and after filtration.

\begin{tabular}{cccc}
\hline Parameters & Before filtration & After filtration & WHO standards \\
\hline Total coliforms & $9600 / 100 \mathrm{ml}$ & $240 / 100 \mathrm{ml}$ & $0 / 100 \mathrm{ml}$ \\
E. coli & $160 / 100 \mathrm{ml}$ & $0 / 100 \mathrm{ml}$ & $0 / 100 \mathrm{ml}$ \\
Fecal streptococci & $65 / 100 \mathrm{ml}$ & $0 / 100 \mathrm{ml}$ & $0 / 100 \mathrm{ml}$ \\
\hline
\end{tabular}

Source: result of the analyses DGEAU, 2014.

Table 4. Results of the bacteriological parameters of water from the lagoon before and after filtration.

\begin{tabular}{cccc}
\hline Parameters & Before filtration & After filtration & WHO standards \\
\hline Total coliforms & $5260 / 100 \mathrm{ml}$ & $50 / 100 \mathrm{ml}$ & $0 / 100 \mathrm{ml}$ \\
E. coli & $360 / 100 \mathrm{ml}$ & $0 / 100 \mathrm{ml}$ & $0 / 100 \mathrm{ml}$ \\
Fecal streptococci & $2720 / 100 \mathrm{ml}$ & $0 / 100 \mathrm{ml}$ & $0 / 100 \mathrm{ml}$ \\
\hline
\end{tabular}

Source: result of the analyses DGEAU, 2014.

\subsection{Debit}

During filtration we found that for well water, the flow rate was 2.5 liter in 3 hours and for water from lagoon of 2.5 liter in 9 hours.

\section{Discussion}

The physico-chemical and microbiological analyzes were conducted in the laboratory of water quality control in the General Directorate of Water in Benin; an authorized laboratory for the monitoring of the quality of drinking water in the country.

The results have shown the effectiveness of the "filtre Songhai" for the well water as well as water from the lagoon, on the microbiological parameters and some physico-chemical parameters.

As regards to physico-chemical parameters such as $\mathrm{pH}$, conductivity, nitrates and nitrites, a difference of values is observed. This could be explained by the properties of clay used in the manufacture of this material. Some physicochemical parameters also differ from the standards prescribed by WHO: in the case of the conductivity (lagoon water), and ammonium, which in the presence of high pH becomes highly toxic for human. The presence of ammonium, nitrates, nitrites and phosphates in the water indicate chemical contamination caused by discharges of sewage and garbage dumps on the edge of the lagoon. The low level of nitrates observed at the 
lagoon despite the heavy pollution could be explained by the presence of aquatic plants that require nitrates for growth and acting as a biological treatment.

As for microbiological parameters, the use of filter has decreased remarkably concentrations of total coliforms (99.05\% for water of the lagoon and $97.5 \%$ for well water) as well as coliforms and fecal streptococci (100\%). In general, the quality of water used by people, both well water as well as surface water is far from satisfactory. The concentrations of microbiological parameters observed were far beyond the standards set by the WHO. The microbiological parameters are influenced by factors such as distance and position between the wells and latrines, especially when the technologies used for latrines do not meet the sealing standards to prevent contamination of the groundwater [3]. This probably explains the high concentration of fecal coliforms, fecal streptococci as well as the total coliform, found in the well water.

Well water was taken from a place where households do not have access to water supplied by the national water company. This source is also shared with other households in the neighborhood who use the well water for domestic purposes. Our results demonstrate that these water sources are unsuitable for consumption and are consistent with results of Akodogbo [7] which reveal the presence of a large number of fecal coliforms, Salmonella, Shigella, Escherichia coli in well water as well as surface water which communicate with the lagoon of Porto Novo.

After filtering, the microbiological quality of the effluent obtained is much better. These results are comparable to the study by Moubokounou [8]. It therefore appears that the use of "filtre Songhai" is relatively effective for microbiological treatment, which considerably reduces the health risk to populations. The "filtre Songhai" is easy to use, have a long life and are affordable (30 euro) to all households. However, their effectiveness against the virus has not been proven [5].

The main limitation to their use is the low speed of the filtration rate. In our experiment, the observed rate 2.5 liters in 3 hours for well water is less than $1 \mathrm{~L}$ /hour; 2.5 liters in 9 hours for water in the lagoon, or $0.25 \mathrm{~L} /$ hour. These flow rates are very low compared with the filtration rate of 1 to 2 liters per hour suggested by Vinka et al. [5]. This major drawback makes using "Filtre Songhai" limited to households whose size is often important in Benin [6]. However, in keeping the efficiency demonstrated by our results, we recommend the use of these filters for drinking water mainly for children under 5 years, the most vulnerable group to water-related health risks. It appears important to continue research in order to improve the filtration rate of filter ceramics manufactured locally.

\section{Conclusion}

At the end of this study, it arises that the use of the "Filtre Songhaï" allows a significant improvement of the microbiological properties of water. Later research is needed to improve the speed of filtration of the "Filtre Songhaï”.

\section{References}

[1] OMS/UNICEF (2013) Progrès en matière d'assainissement et d'alimentation en eau. Rapport-OMS, 40 p.

[2] Hunter, P., MacDonald, A.M. and Carter, R.C. (2010) Water Supply and Health. PLoS Medicine, 7, e1000361. http://dx.doi.org/10.1371/journal.pmed.1000361

[3] Degbey, C., Makoutodé, M., Agueh, V., Dramaix, M. and de Brouwer, C. (2011) Facteurs associés à la qualité de l'eau de puits et prévalence des maladies hydriques dans la commune d’Abomey-Calavi (Bénin). Cahier Santé, 21, 47-55.

[4] Higy, C. and Laurent, C. (2011) Analyse de la qualité de l'eau de puits transformés. Un exemple d'application au Bénin, Juillet, 23 p.

[5] Vinka, A. and Oyanedel-Craver, J.A.S. (2008) Sustainable Colloidal-Silver-Impregnated Ceramic Filter for Point-ofUse Water Treatment. Environmental Science \& Technology, 42, 927-933. http://dx.doi.org/10.1021/es071268u

[6] INSAE Bénin (2013) Résultats provisoires du RGPH4. http://www.insae-bj.org/recensement-population.html

[7] Akodogbo, H. (2005) Contribution à l'amélioration de la qualité de l'eau à usage domestique dans le 5ème arrondissement de la commune de Porto-Novo-Bénin. Mémoire DESS en environnement et santé. Abomey Calavi: UAC.

[8] Moubokounou, G. (2010) Techniques de traitement de l'eau à domicile: Evaluation de l'efficacité des filtres en céramique. Mémoire de Master, Ouagadougou: 2IE. 